\title{
Curbing Post Harvest Losses for Food Security: A Survey of Smallholder Farmers in Ethiopia
}

\author{
Robert Agunga ${ }^{1, *} \&$ Ruth Sleshi ${ }^{2}$ \\ ${ }^{1}$ Department of Agricultural Communication, Education and Leadership, The Ohio State University, USA \\ ${ }^{2}$ International Development Studies, The George Washington University '18, Elliott School of International Affairs, \\ USA \\ *Correspondence: Department of Agricultural Communication, Education and Leadership, The Ohio State University, \\ USA. E-mail: agunga.1@osu.edu
}

Received: July 7, 2018

Accepted: July 20, 2018 Online Published: July 25, 2018

doi:10.5430/wjss.v5n2p51

URL: https://doi.org/10.5430/wjss.v5n2p51

\begin{abstract}
Reducing post harvest losses (PHL) offers great promise for curbing hunger and reducing food insecurity in Africa. A World Bank 2011 report on Missing Food estimated that if African farmers can reduce PHL by even one percent that will be an annual savings of US\$40 million for Sub-Saharan Africa alone. Our survey of 88 smallholder farmers in the Gondar Region of Ethiopia found that farmers faced serious to most serious losses caused by rodents, birds and the weather. About $46 \%$ of the respondents, expressed serious problems with rodents; $54 \%$ had serious problems with birds and even higher numbers, $55 \%$ and $63 \%$ had serious problems with the weather and pests, respectively. Another $28.4 \%$ of the farmers complained of very serious problems with birds while half of them had very serious problems with rodents. Many of the PHL problems seem to emanate from poor storage. The University of Purdue, USA, has invented what it calls the "Purdue Improved Crop Storage Bag," which is advertised as highly efficient and relatively inexpensive. We urge agricultural extension systems in Africa to test the effectiveness of this bag before recommending it to their grain farmers as a means of reducing PHL.
\end{abstract}

Keywords: postharvest losses, Ethiopia, food security, grain losses, agricultural extension agents

\section{Introduction}

\subsection{Post Harvest Loss in Food Production}

Post harvest refers to the time when the grain or fruit, the edible commodity, is separated from the plant by human action for consumption (Reddy, Rajeswari \& Sudhakar, 2014; Imhomoh, 2012). The post-harvest period ends when the food reaches the final consumer. "Food loss" refers to any change in the availability, edibility, wholesomeness or quality of the food that prevents it from being consumed by people (Naz \& Abdullah, 2015). Postharvest Loss (PHL) refers to the quantitative and qualitative losses of grain or fruit between harvesting and when it reaches the final consumer and includes grain eaten by rodents, insects, birds or molded grain due to poor drying (Lucia and Assennato, 1994).

The causes of PHL may include harvesting methods, handling procedures, drying techniques and moisture levels. Other causes can include contamination, attacks by rats, birds, and pests, insect damage, and infestation by food-borne pathogens (World Bank, 2011). A significant amount of grain lost after harvest, can exasperate hunger or result in substantial loss of income for farmers, at times postharvest losses which can account for up to 30 percent of farm production (Lucia and Assennato, 1994). More efforts are needed to prevent PHL and to improve agricultural production and food security in developing countries (World Bank, 2011). Post harvest losses prevention contributes to reducing poverty by increasing income earning opportunities for farmers.

Reducing PHL, increases the amount of food available for consumption and ensures food security (Goletti \& Wolff, 1999). A number of development organizations conducting research in PHL include The Food and Agriculture 
Organization of the United Nations (FAO), the African Development Bank (AfDB) and The European Union. The AfDB president, Dr. Akinwunmi Adesina, said that post-harvest losses in Africa are equivalent to the annual caloric requirement of 48 million people, and worth US \$4 billion in lost revenue per year. Therefore, the organization has emphasized the need for policy regulations to end losses on the continent that spends $\$ 35$ billion yearly on food imports. The Bank's President noted, "Massive quantities of food crops, fresh fruits and vegetables and dairy products go to waste in rural areas, while Africa depends on food imports" (2016, p. 1). The Bank reduces PHL by educating farmers who receive its agricultural development loans. The European Union also supports PHL research by financing the African Postharvest Losses Information System (APHLIS), which provides accurate data on PHL in Africa (Rembold, Hodges, Bernard, Knipschild \& Léo, 2011).

\subsection{Post Harvest Loss in Ethiopia}

Ethiopia is experiencing the fastest economic growth rate in Africa, at $8.7 \%$ in 2015, but it also ranks lowest when it comes to food security (Davison, 2016). With a population of almost 100 million, Ethiopia is the $13^{\text {th }}$ largest most populous country in the world. As shown in the graph below, the rural population in Ethiopia has been growing since 1960. It has gone from 20,726,230 in 1960 to 80,037,000 in 2015, a period of 55 years (United Nations, World Urbanization Prospects, 2016). $80 \%$ of the population earns a living in subsistence agriculture and more than 12 million of whom face food shortages on an annual basis, calling for a dire need of transformation (Chayalew, Adenew \& Melow, 2010). With this vast population of subsistence farmers, PHL can be a serious threat to famine.

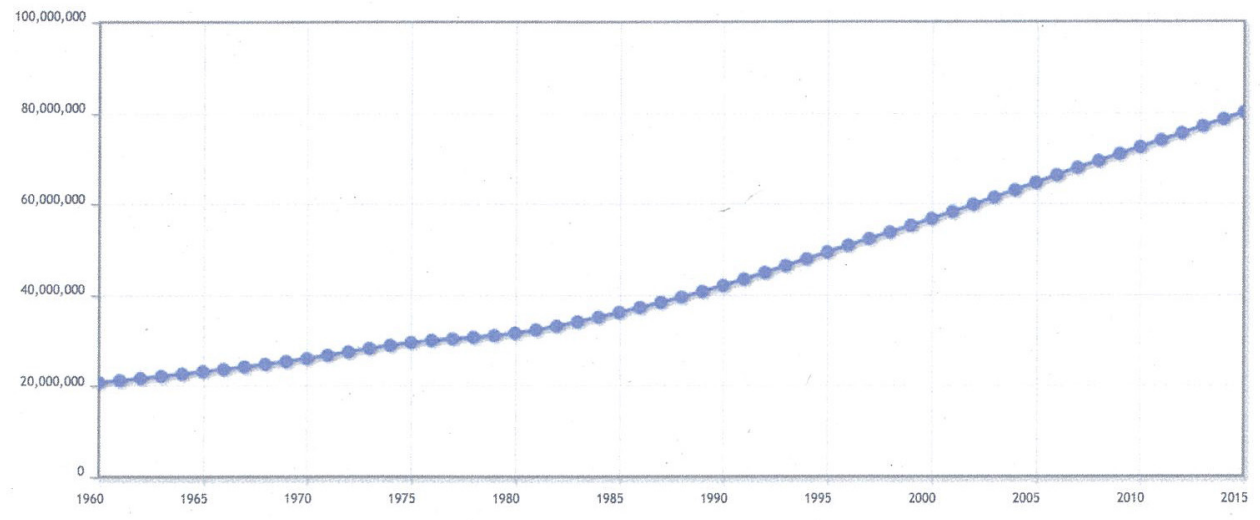

Figure 1. Increase in Ethiopia'S Rural Population, from 1960 to 2015

Source: United Nations, World Urbanization Prospects, 2016

The country produces a variety of staple crops such as teff, wheat, maize, sorghum and barley. Teff is fine grained - about the size of a poppy seed, and comes in a variety of colors, from white and red to dark brown, and grows almost exclusively in Ethiopia and Eritrea (The Teff Company, 2015). In 2012, postharvest losses in Ethiopia for teff were estimated at $12.3 \%, 11.6 \%$ for sorghum, $9.9 \%$ for wheat, and $16.8 \%$ for maize (Natural Resources Institute, 2015). Studies in Ethiopia identified the following problems as PHL causes: excessive rainfall and inadequate storage facilities, which, in turn, cause insect infestation as the primary cause of PHL in Ethiopia (Boxall, 1998).

Since smallholder farmers are the main grain producers and using crude postharvest handling methods, it is not surprising that significant drops in yield occur. In Ethiopia, food security is particularly acute in the Amhara National Regional State and more specifically, the Gondar Region. Demographic and Health surveys for Ethiopia in 2005 and 2011 indicated the Amhara National Regional State, with a population of roughly 25 million people, had the highest rate of childhood stunting, 57\% in 2005 and $52 \%$ in 2011 (Ethiopian Demographic Health Survey of 2005 and 2011). Historical records further indicate that childhood malnutrition in the region has increased over the last 50 years (Dibsdall, Lambert, Robbin \& Frewer, 2003). The combination of hunger, malnutrition and chronic diseases affect the vast majority of women and children, causing stunted growth and premature mortality. We believe that more intensive research is needed to determine the causes of PHL for many poor and food deficient countries, like Ethiopia. Research in the Amhara Region of Gondar is especially necessary because it is one of the most densely populated and impoverished areas of Ethiopia. 
As a grain growing country, understanding the causes of postharvest loss is necessary to maximize farm yields. This study examined the problem of PHL in Gondar with the goals of estimating and finding the causes of postharvest losses in order to further improve food availability.

\subsection{Purposes and Objectives}

The overall purpose of the study was to examine the level of postharvest losses among smallholder grain farmers in the Gondar Region of Ethiopia. The specific objectives were:

1. To identify the demographic characteristics of grain producers in northern Ethiopia;

2. To examine constraints smallholder grain farmers face;

3. To examine the magnitude of PHL in the region;

4. To examine the impact of extension workers in overcoming PHL; and

5. To determine correlations between demographic characteristics and PHL.

\section{Method}

\subsection{Data Collection Method and Targeted Participants}

The data was collected through face-to-face interviews using a survey questionnaire. The study population consisted of heads of households, both men and women in the Gondar Region of Ethiopia. A convenient sample of 88 households were surveyed. No systematic sample selection method was used as the houses are scattered and are not numbered. A household refers to a family unit, it can be nuclear, such as husband, wife and children or an extended family, where other relatives, such as grandparents, are included. In the context of this region, the head of the household is usually the husband, but it can be a woman in the case of a divorced family or widow. The study specifically focused on households that earn a living on the land.

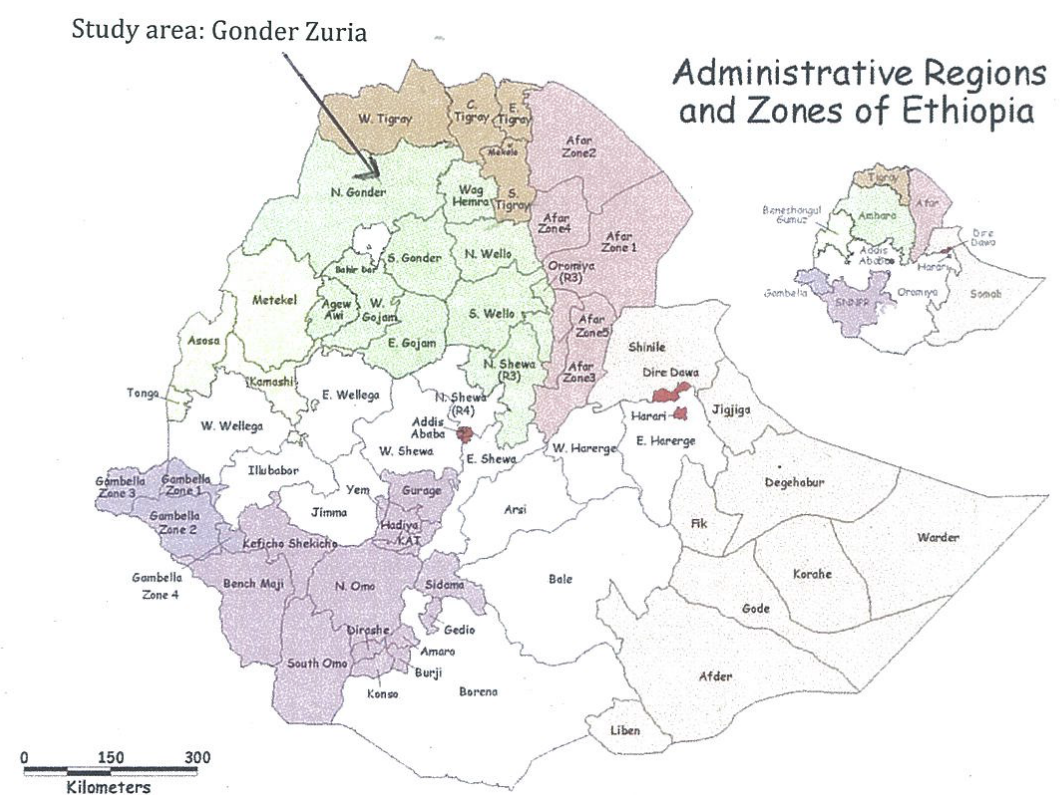

Figure 2. Map of Gondar Region of Ethiopia Showing Study Area

\subsection{Targeted Location and Sampling Procedures}

Ethiopia is divided into nine regions and one of them is the Amhara (Gondar) Region where the study was conducted. Amhara Region (or Zone) has 25 million people in roughly 155,000 square kilometers or 94 people per square kilometer density (Ethiopia Population, 2017). Each region is divided into zones and each zone (sub-region) divided 
into districts or woredas (or weredas). These are also further comprised of wards or kebeles, the smallest units of local government in Ethiopia. The study focused on the North Gondar Zone (sub-region) and covered two districts in Gondar Zuria: Tach Teda and Tekil Dengai. Based on the 2007 national census by the Central Statistical Agency of Ethiopia (CSA), the Gondar Zuria (or Zuriya) woreda covers $142.08 \mathrm{~km}$ squared and has a total population of 191,394 (Central Statistics Agency, 2007). According to Gondar Zuriya woreda agricultural development office report, it has 35 rural kebeles and two urban Kebeles. However, due to financial and time limitations, only a purposive sample selection of 88 heads of households (male and female) from the two rural kebeles (Tach Teda and Tekil Dengai) were surveyed (44 per woreda). Since the selection process was not random, the findings cannot be generalized to farmers throughout the country or even the region.

\subsection{Data Collection and Data Analysis}

In the data collection, the interviewer, who spoke both English and Amharic, asked questions to farmers (the respondents) in Amharic (the local and national language) and recorded their responses in English. Validity and reliability of the instrument were tested before use (Joppe, 2000). Data collection was carried out in June and July of 2015 following approval of the study by the Ohio State University Research Office. The SPSS was used for data entry and analysis and descriptive statistics consisting of mean, frequency and percentage were reported.

\section{Results}

\subsection{Demographic Characteristics of Respondents}

The main demographic characteristics observed were age, level of education and farm size. Age was important as it relates to on-farm experience. Of the 88 smallholder farmers interviewed, $89.8 \%$ (79) were male and $10.2 \%$ (9) were female. The average age range of the farmers was between 30 and 50 years with the median age being 44 years old. Five respondents (5.7\%) were aged 25 years or less; 11 (12.5\%) were between the ages of 26 and 30 years; 24 members $(27.3 \%)$ were aged 31 - 40 years; a sizable majority $22(25 \%)$ were aged $41-50$ years; $14(15.9 \%)$ were 51 - 60 years old; and 12 respondents (13.6\%) were 61 years and older (Figure 3 ).

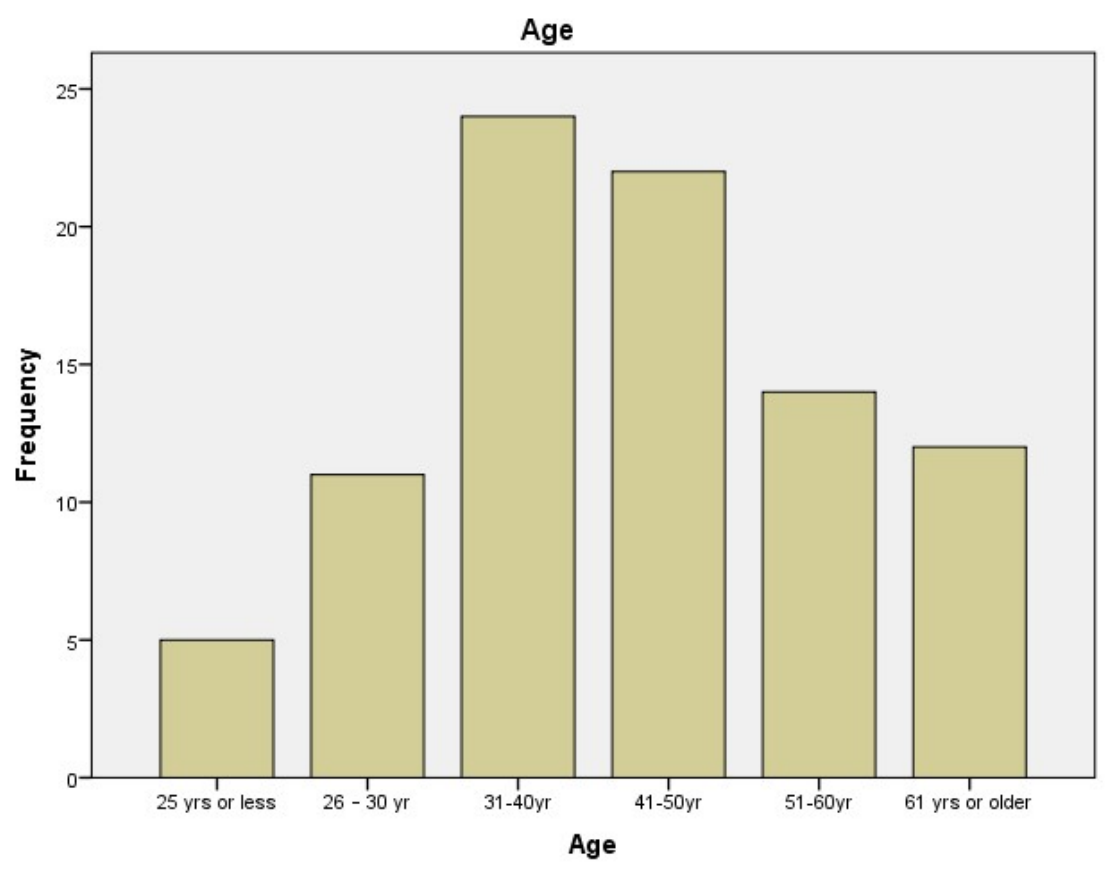

Figure 3. Age Distribution of Respondents

With regard to education, the majority of farmers $(43.3 \%)$ had no formal education while $29(33 \%)$ had $1^{\text {st }}$ to $4^{\text {th }}$ grade education. The remaining $21(23.9 \%)$ had educational levels ranging from $5^{\text {th }}$ to $8^{\text {th }}$ grade. Only $9 \%$ had 
education beyond the $8^{\text {th }}$ level.

The family sizes were generally large. Ten respondents (11.4\%) had families of three people or less; $39(44.3 \%)$ had family sizes of $4-6$ people; $29(33.0 \%)$ had family sizes of 7-8 people; while $10(11.4 \%)$ of respondents had family sizes of 9 or more people.

\subsection{Respondents' Economic Status}

Another demographic characteristic, economic well-being of respondents, was measured in terms of: a) access to good drinking water, $b$ ) whether their homes were roofed with aluminum or grass, c) access to a private toilet for the family, d) source of energy for cooking, e) whether they owned radios, f) whether they owned cell phones, and g) whether they had bank accounts.

Regarding sources of drinking water, the majority of farmers, $55(62.5 \%)$, used public piped water systems; 18 $(20.5 \%)$ used rivers or streams, and $11(12.5 \%)$ used wells. Having an aluminum roof is considered a sign of wealth in Ethiopia and many countries in Africa. Nearly all the roofs of the farmers' homes were aluminum (95.5\%) while a small number of farmers' roofs were grass. With respect to sanitation, 65 (73.9\%) had private latrines, 4 respondents $(4.5 \%)$ used public latrines and $19(21.6 \%)$ used open places. With respect to sources of energy for cooking virtually all respondents used firewood. Eighty-three (94.3\%) mentioned firewood as a source of energy for cooking while 5 $(5.7 \%)$ mentioned charcoal as their source of energy for cooking. These can imply problems of deforestation and soil erosion as they suggest a cutting of the forest for firewood.

Regarding personal possessions, only 26 respondents (29.5\%) owned radio sets (or had access to radio broadcast); 35 respondents (39.8\%) had mobile phones, and only $41(53.4 \%)$ had bank saving accounts. For their most prized possessions, the majority of the farmers mentioned livestock or farmland. Nearly all the farmers $(90 \%)$ own livestock. Eighty-two (92.0\%) owned cattle. Of the cattle owners, $22(25.0 \%)$ had $1-3$ herds, $39(44.3 \%)$ had $4-6$ cattle and $9(10.2 \%)$ had 7 or cattle or more. Not surprisingly, Ethiopia is the largest producer of cattle in Africa. According to government statistics, there are approximately 50 million cattle, 50 million goats and sheep, as well as an assortment of horses, donkeys, camels and chickens (The International Trade Administration, 2017). Sixty-one (69.3\%) our study respondents had chickens ( $1-7$ in number); 32 (36.4\%) had sheep and 31 (35.2\%) mentioned donkeys. On farm size, 67 respondents $(76.1 \%)$ had farm sizes measuring roughly one hectare, $9(10.1 \%)$ averaged three hectares and only 6 had four hectares or more. Six respondents did not mention their farm sizes.

\subsection{Sources of Post Harvest Loss of Grains}

Farmers were asked whether they experienced grain losses from rodents, mold, birds, weather and pests. They were asked to rank their experiences in a continuum based on the level of seriousness of the problem - from "Not serious" through "Serious" to "Very Serious" as shown in Table 1. Rodents were ranked as "serious" to "most serious" by 84 respondents $(95.5 \%)$ followed by pests mentioned by 73 respondents $(83.0 \%)$ of respondents, birds, ranked serious to very serious by 72 farmers $(81.8 \%)$ and then the weather, by 64 farmers $(72.7 \%)$ of respondents. Mold was viewed by many of the farmers as not a serious problem according 75 or $85.2 \%$ of respondents. A quarter of respondents felt the weather was not a problem although close to three quarters of respondents viewed it as a problem.

Table 1. PHL of Grain as Expressed by Farmers

\begin{tabular}{llllll}
\hline & Rodents & Birds & Mold & Weather & Pests \\
\hline $\begin{array}{l}\text { Not } \\
\text { Serious }\end{array}$ & $\mathrm{N}=1$ & $\mathrm{~N}=11$ & $\mathrm{~N}=75$ & $\mathrm{~N}=22$ & $\mathrm{~N}=9$ \\
Serious & $\mathrm{N}=40$ & $\mathrm{~N}=47$ & $\mathrm{~N}=8$ & $\mathrm{~N}=48$ & $\mathrm{~N}=60$ \\
$\begin{array}{l}\text { Very } \\
\text { Serious }\end{array}$ & $\mathrm{N}=44$ & $\mathrm{~N}=25$ & $\mathrm{~N}=2$ & $\mathrm{~N}=16$ & $\mathrm{~N}=13$ \\
\hline
\end{tabular}

\subsection{Quantity of PHL}

Farmers were asked to estimate the quantity of their losses in kilograms. The vast majority of them placed the losses at 50 kilograms or less $(\mathrm{N}=84(95.5 \%)$. This was followed by 78 respondents $(88.6 \%)$ who said their losses ranged 
from $51-100 \mathrm{~kg}$ with 26 farmers (29.5\%) who said it ranged from 101- $200 \mathrm{~kg}$ and another 24 farmers saying it averaged more than $200 \mathrm{~kg}$. Teff, maize and sorghum seemed to carry the highest losses while millet had the least losses. Only three farmers mentioned losses of 301 to $400 \mathrm{~kg}$ while only two farmers mentioned losses over $400 \mathrm{~kg}$.

Table 2. Number of Farmers Experiencing Postharvest Grain Losses

\begin{tabular}{lllllll}
\hline Estimated losses $(\mathrm{kg})$ & Teff & Chick Pea & Maize & Sorghum & Millet & Total $N$ \\
\hline 50 & 30 & 12 & 25 & 10 & 7 & 84 \\
$51-100$ & 18 & 14 & 24 & 20 & 2 & 78 \\
$101-200$ & 6 & 4 & 12 & 4 & 0 & 26 \\
$201-300$ & 4 & 5 & 4 & 6 & 0 & 19 \\
$301-400$ & 0 & 1 & 2 & 0 & 0 & 3 \\
$401+$ & 1 & 1 & 0 & 0 & 0 & 2 \\
\hline
\end{tabular}

\subsection{Yields and Types of Losses}

The majority of respondents have been farming for over twenty years and stated that farming is the only occupation they have known. Farmers were asked to estimate quantitatively (in kilograms), the yields from their farms. An attempt was made to explain to them what a kilogram is by using local measuring methods, such as showing a basket and asking how many of those filled basket will they get from the farm. Fifty kilograms, for example, is equivalent to $110 \mathrm{lbs}$ or a bag of produce. Subsistence farmers are expected to get $2-4$ bags per acre. Thus, although the farm size was not indicated, a person who harvests 4 bags of maize can be estimated to have cultivated an acre or two. Table 3 shows farmers' estimation yields for four crops - maize, sorghum, chicken pea and millet. Depending on whether they used fertilizer and other modern inputs, the table shows that many of them operate at the subsistence level - that is, obtaining $600 \mathrm{~kg}$ per acre. For teff, 74 respondents (84.0\%) reported compared to 29 respondents (33\%) who achieved the 600 or less kilograms in yields with maize, 47 respondents $(54 \%)$ who achieved the same rate and 39 respondents $(44.3 \%)$ with chickpeas and $24(27.3 \%)$ with millet.

Table 3. Farmer's estimation of yields for Maize, Sorghum, Chickpea and Millet

\begin{tabular}{lllllllll}
\hline Quantity (kg) & \multicolumn{2}{c}{ Maize } & \multicolumn{3}{c}{ Sorghum } & \multicolumn{3}{c}{ Chickpea } \\
\cline { 2 - 9 } & $\mathrm{N}$ & $\%$ & $\mathrm{~N}$ & $\%$ & $\mathrm{~N}$ & $\%$ & $\mathrm{~N}$ & $\%$ \\
\hline$<400$ & 16 & 18.2 & 30 & 34.1 & 30 & 34.1 & 22 & 25.0 \\
$401-600$ & 13 & 14.8 & 17 & 19.3 & 9 & 10.2 & 2 & 2.3 \\
$601-800$ & 11 & 12.5 & 2 & 2.3 & 7 & 8.0 & 0 & 0 \\
$801-1000$ & 6 & 6.8 & 7 & 8.0 & 0 & 0 & 0 & 0 \\
1001 or more & 2 & 2.3 & 0 & 0 & 1 & 1.1 & 0 & 0 \\
Total & 48 & 54.5 & 56 & 63.6 & 47 & 53.4 & 24 & 27.3 \\
System Missing & 40 & 45.5 & 32 & 36.4 & 41 & 46.6 & 64 & 72.7 \\
Total & 88 & 100.0 & 88 & 100.0 & 88 & 100.0 & 88 & 100.0 \\
\hline
\end{tabular}

Next, we examined the nature of the postharvest losses. We asked farmers to indicate the types of postharvest losses they incurred and the intensity of the losses, such as "minimal" loss, "significant" loss or "highest" loss (Table 4). They were to specify whether the losses occurred during transportation, harvesting, drying, threshing, winnowing and so on. In general, the vast majority of farmers reported experiencing "no losses" to "minimal losses." Only a small minority reported experiencing significant or highest losses. For example, 17 respondents $(\mathrm{N}=17(19.3 \%)$ reported experiencing losses during winnowing whereas only 4 farmers $(\mathrm{N}=4(4.5 \%)$ reported experiencing highest losses during harvesting. 
Table 4. Types of Postharvest Losses as Expressed by Smallholder Farmers

\begin{tabular}{lllll}
\hline Activity & No Loss & Minimum Loss & Significant Loss & Highest Loss \\
\hline Transporting & $\mathrm{N}=38(43.2 \%)$ & $\mathrm{N}=31(35.2 \%)$ & $\mathrm{N}=5(5.7 \%)$ & $\mathrm{N}=1(1.1 \%)$ \\
Harvesting & $\mathrm{N}=34(38.9 \%)$ & $\mathrm{N}=37(42.7 \%)$ & $\mathrm{N}=6(6.8 \%)$ & $\mathrm{N}=4(4.5 \%)$ \\
Drying & $\mathrm{N}=40(48.9 \%)$ & $\mathrm{N}=42(46.6 \%)$ & $\mathrm{N}=5(5.7 \%)$ & $\mathrm{N}=1(1.1 \%)$ \\
Threshing & $\mathrm{N}=38(43.2 \%)$ & $\mathrm{N}=41(47.7 \%)$ & $\mathrm{N}=2(2.3 \%)$ & $\mathrm{N}=2(2.3 \%)$ \\
Winnowing & $\mathrm{N}=11(12.5 \%)$ & $\mathrm{N}=43(48.9 \%)$ & $\mathrm{N}=17(19.3 \%)$ & - \\
Storing & $\mathrm{N}=55(62.5 \%)$ & $\mathrm{N}=48(54.5 \%)$ & $\mathrm{N}=8(9.1 \%)$ & - \\
Grinding & $\mathrm{N}=52(59.1 \%)$ & $\mathrm{N}=15(17.0 \%)$ & $\mathrm{N}=3(3.4 \%)$ & $\mathrm{N}=1(1.1 \%)$ \\
Marketing & $\mathrm{N}=18(20.5 \%)$ & $\mathrm{N}=5(5.7 \%)$ & - & - \\
\hline
\end{tabular}

\subsection{Farmers' Access to Extension Servies}

Smallholder grain farmers' access to extension education is crucial to curbing post harvest losses in Ethiopia or anywhere else in the developing world. However, it was not clear how many farmers have access to extension. About $70 \%$ of the farmers responded that their extension workers had advised them on how to handle postharvest losses. Another $13 \%$ of the farmers said they received no extension education on PHL while still another 13\% said they sometimes received extension education. Given the paucity of extension performance in Ethiopia, we do suspect that extension performance at $70 \%$ high may have been exaggerated or that the question may not have been properly worded. Dating back to the 1970s, the Ethiopian government placed emphasis towards improving the agricultural sector by increasing smallholder farmers' access to modern inputs and extension services (Spielman, Kelemwork \& Alemu, 2011). Prior to this date, successive governments had focused on large-scale farmers, especially cash crop coffee and tea growers with the aim of boosting the country's agricultural exports (Berhanu, 2012). However, the need to increase food production to feed the country's burgeoning population, has led to increased emphasis on provision of agricultural extension services (Berhanu \& Poulton, 2014). Regardless, it is noted that the provision of agricultural extension services in Ethiopia is highly politicized since smallholder farmers constitute the majority of the electorate and, as such, provision of extension services is used as a tool for winning elections (Berhanu \& Poulton, 2014).

Additionally, the administration of extension services through cooperatives limits participation of the poor and marginalized groups, such as, women as they are often not included in decision-making processes (Bernard, \& Spielman, 2009). In summary, the quality of extension services in Ethiopia leaves a lot to be desired for several reasons. For one, extension workers seem poorly trained; for another there is increased political interference; and for yet another, marginalized farmers and women are often not involved in extension decision-making (Belay \& Abebaw, 2004; Elias, et al., 2016). It is not surprising, therefore, if grain producers fail to receive extension education on PHL.

\subsection{Correlations between Demographic Characteristics}

In this section, examined relationships between two or more variables using the Pearson product- moment correlation coefficient (r) (Table 5). Pearson product-moment correlation coefficient (r) was computed to assess the relationship between age of respondent and family size, land size and family size, age of respondent and experience in farming, and so forth. Table 5 presents the findings. There was a very strong positive association between age of respondent and farming experience, $(\mathrm{r}=.75, \mathrm{~N}=74, \mathrm{p}<=.01)$. This means that older farmers claimed to have more experience than younger farmers. There were also moderate positive associations found between land size and family size, that is, large families tended to have larger farms. 
Table 5. Correlation Analysis

\begin{tabular}{|c|c|c|c|c|c|c|c|c|}
\hline & \multicolumn{8}{|c|}{ Correlations } \\
\hline & Age & FamSize & LandSize & Exp & Saving & Donkey & ProdSorghum & ProduceTeff \\
\hline Age & 1 & & & & & & & \\
\hline FamSize & $.394 * *$ & 1 & & & & & & \\
\hline LandSize & .193 & $.287 * *$ & 1 & & & & & \\
\hline Exp & $.750 * *$ & $.302 * *$ & .042 & 1 & & & & \\
\hline Saving & -.012 & -.104 & .184 & -.046 & 1 & & & \\
\hline Donkey & -.076 & -.153 & $.476^{* *}$ & -.360 & .048 & 1 & & \\
\hline ProdSorghum & -.168 & -.011 & $.292 *$ & $-.290 *$ & .018 & $.622 * *$ & 1 & \\
\hline ProduceTeff & -.063 & $.225^{*}$ & -.114 & -.005 & -.220 & -.122 & $.320 *$ & 1 \\
\hline
\end{tabular}

There was also strong positive relationship between producers of sorghum (pro-sorghum) and ownership of donkeys $\mathrm{r}=.622, \mathrm{~N}=88, \mathrm{p}=<.01$. However, the relationship between land size and ownership of donkeys was moderate, $\mathrm{r}=.476$, $\mathrm{N}=88, \mathrm{p}=<.01$ ). Also, a moderate positive relationship was found between age and family size, $\mathrm{r}=.394, \mathrm{~N}=88$, $\mathrm{p}=<.01)$. There was also a moderate positive relationship between producers of sorghum and producers of teff. Still yet, we observed a weak, positive relationship producer of sorghum and land size, $\mathrm{r}=.292, \mathrm{~N}=88, \mathrm{p}=<.05$ ). We also observed a weak negative relationship between farming experience and producers of sorghum, $\mathrm{r}=.290, \mathrm{~N}=88$, $\mathrm{p}=<.05)$. Lastly, we found a weak positive relationship between family size and producers of teff, $(\mathrm{r}=.225, \mathrm{~N}=88$, $\mathrm{p}=<.05$ ). It should be warned that these relationships in no way imply causality. Co-relationship simply means that variation in the scores on one variable correspond with variation in the scores on a second variable. Causation, on the other hand, means that variations in the scores on one variable cause or create variation in the scores on a second variable (Urdan, 2005).

\section{Discussion and Recommendations}

It is generally claimed in the literature that PHL is a major problem in developing countries. For example, we noted in the introduction, the World Bank's claim that a one percent reduction in PHL can result in US\$40 million savings for Sub-Saharan Africa alone. The AfDB president, Dr. Akinwunmi Adesina, had also noted that post-harvest losses in Africa is worth US \$4 billion in lost revenue per year while "massive quantities of food crops" go to waste in rural areas. Our survey of 88 smallholder farmers in the Gondar Region of Ethiopia found that although the farmers complaint of serious losses caused by rodents, birds and the weather, the quantities lost was described as minimal at best. The worse losses probably occur at harvesting, when the fields are over dried, or winnowing, especially during strong winds. Much waste also occurring during storage. We noted that the University of Purdue has invented the Purdue Improved Crop Storage Bag, which is described as a relatively simple, efficient and inexpensive method of grain storage (Obiria, 2014). We recommend that extension workers study this technology sufficiently before urging its adoption by farmers.

We found that Ethiopian farmers cultivate small acreages and try to derive maximum yields from these pieces of land. Concern with post harvest losses is therefore high on their minds. Ethiopian grain producers still use traditional methods of storage, which can expose their yields to rodents, insects and mold leading to losses. We found that post harvest losses are hard to measure, hence the tendency to exaggerate these losses. However, the use of efficient harvesting, storage and allied technologies can significantly reduce PHL and farmers should be encouraged to use these technologies, especially if they are affordable.

Perhaps, the main problem smallholder farmers face is access to extension services. Extension can provide farmers with useful information on PHL. Although the Government of Ethiopia is committed to ensuring national food self-sufficiency by subsidizing farm inputs and increasing the numbers of extension workers, the quality of extension workers remain poor. The challenge lies in strengthening the capacity of extension workers through training and 
improved reward systems.

Overall, curbing PHL is an important way to achieving food security and poverty reduction. Food that farmers have toiled to produce should not be allowed to go missing through improper care. Extension workers should intensify extension education on PHL.

\section{References}

Akinwunmi Adesina. (2016). Speech delivered by President Akinwumi Adesina of the African Development Bank, at the African Green Revolution Forum, September 8, 2016, Nairobi, Kenya. Retrieved from https://www.afdb.org/fileadmin/uploads/afdb/Documents/GenericDocuments/Keynote_Speech_delivered_by_D r._Akinwumi_A._Adesina_President of the_African_Development_Bank_Group _at the Africa_Green_Rev olution_Forum__Nairobi____September_2016.pdf

Belay, K., \& Abebaw, D. (2004). Challenges Facing Agricultural Extension Agents: A case Study from South western Ethiopia. African Development Review, 16(1), 139-168. https://doi.org/10.1111/j.1467-8268.2004.00087.x

Berhanu, K., \& Poulton, C. (2014). The political economy of agricultural extension policy in Ethiopia: economic growth and political control. Development Policy Review, 32(s2), 197-213. https://doi.org/10.1111/dpr.12082

Berhanu, K., (2012). The political economy of agricultural extension policy in Ethiopia: economic growth and political control (Working paper). Produced as part of the FAC Political Economy of Agricultural Policy in Africa (PEAPA) work stream. https://opendocs.ids.ac.uk/opendocs/bitstream/handle/123456789/2246/FAC_Working_Paper_042.pdf?sequence $=1$

Bernard, T., \& Spielman, D. J. (2009). Reaching the rural poor through rural producer organizations? A study of agricultural marketing cooperatives in Ethiopia. Food policy, 34(1), 60-69. https://doi.org/10.1016/j.foodpol.2008.08.001

Boxall, R. (1998) Grains post-harvest loss assessment in Ethiopia: Final report.

Central Statistics Agency. Census 2007 Tables: Amhara Region, Tables 2.1, 2.4, 2.5, 3.1, 3.2 and 3.4. Retrieved from $\mathrm{http} / / \mathrm{www} . \mathrm{csa} \cdot$ gov.et/index.php?option $=\mathrm{com} \_$rubberdoc\&view $=\mathrm{doc} \& \mathrm{id}=266 \&$ format $=$ raw\&Itemid $=521$

Chayalew, G., Adenew, B., \& Melow, J. (2010). Ethiopia's Agricultural Sector Policy \& Investment Framework (PIF) 2010-2020.

Davison, W. (2016). World's fastest growing economy Ethiopia is new flavor of the month for development strategies that work. Country experiences presented at the ECOSOC Annual Ministerial Review. Retrieved from http://webapps01.un.org/nvp/indpolicy.action?id=124

Dibsdall, L.A., Lambert, N., Robbin, R.F., \& Frewer, L.J. (2002). Low-income consumers' attitudes and behavior towards access, availability and motivation to eat fruit and vegetables. Public Health Nutrition, 6(2), 159-168.

Ethiopia Population. (2017). Retrieved 2017-10-31 from Worldpopulationreview.com/countries/ethiopia -population/

Goletti, F., \& Wolff, C. (1999). The Impact of Postharvest Research. Markets and Structural. Retrieved from http://mgafrica.com/article/2016-02-05-worlds-fastest-growing-economy-ethiopia-is-new-

Imhomoh, O. S. (2012). Post-harvest Losses and Food Sustainability Challenges: A case study of rural maize farmers in Ghana, West Africa.

Joppe, M. (2000). The Research Process, The Quantitative Report Journal, 8(4), 597.

Kassa, B., \& Degnet, A. (2004). Challenges Facing Agricultural Extension Agents: A Case Study from South -western Ethiopia. African Development Review, 16(1), 139-168. https://doi.org/10.1111/j.1467-8268.2004.00087.x

Lucia, M., and D. Assennato (1994). Agricultural engineering in development: Post-harvest.

Natural Resources Institute (2015). Missing Food: The Case of Postharvest Grain Losses in Sub-Saharan Africa, Report No. 60371-AFR. C 2011 The International Bank for Reconstruction and Development/The World Bank, NRI's Postharvest Loss Reduction Centre.

Naz, S., \& Abdullah, R. (2015). Shelf life extension of Ginger using Gamma Irradiation: Reduction of microbial load 
and post harvest loss prevention of ginger, Aug 5 .

Obiria, M. (2016). New storage bag innovation to reduce post harvest losses, Nation Media Group, Business Daily, Friday, March 4, 2016. Posted Monday, September; The University of California at Davis offers a similar resource center. Retrieved from http://postharvest.ucdavis.edu

Reddy, Y. S. K., Rajeswari V. R., \& Sudhakar, P. (2014). Post harvest losses in sugarcane due to delayed harvest and crush: Effect of delayed harvest and crush in sugarcane.

Rembold, F., Hodges, R., Bernard, M., Knipschild, H., \& Léo, O. (2011). The African postharvest losses information system (APHLIS) 2011. An innovative framework to analyze and compute quantitative postharvest losses for cereals under different farming and environmental conditions in East and Southern Africa.

Rosenberg, M. (2017). Most Populous Countries Today: These Countries Have a Population of Over Fifty Million. Retrieved September 07, 2017 from https://www.thoughtco.com/most-populous-countries-today-1433603

Spielman, D. J., Kelemwork, D., \& Alemu, D. (2011). Seed, fertilizer, and agricultural extension in Ethiopia. Food and agriculture in Ethiopia: Progress and policy challenges, 84-122.

Tanya Stathers, Richard Lamboll \& Brighton M. Mvumi (2013). Postharvest agriculture in changing climates: its importance to African smallholder farmers. Food Security, 5(3), 361-392. https://doi.org/10.1007/s12571-013-0262-z

The Teff Company. (2015, August 23). About Teff. Retrieved from https://teffco.com/what-is-teff/

The International Trade Administration, U.S. Department of Commerce (2017). Ethiopia Livestock. Retrieved from https://www.export.gov/article?id=Ethiopia-Livestock

United Nations, World Urbanization Prospects (2016). Development Department of Economic and Social Affairs, Population Division. Retrieved from http://www.un.org/en/development/desa/population/theme/urbanization/

World Bank (2011). Missing Food: The Case of Postharvest Grain Losses in Sub-Saharan Africa. 